\title{
Managerial Self-efficacy and Discretionary Behavior Improving Work Environment for Small Firm Performance
}

\author{
Mohammed-Aminu Sanda \\ Department of Business Administration, Technology and Social Sciences, Lulea University of Technology, \\ SE- 97187, Lulea, Sweden \\ mohami@ltu.se
}

\begin{abstract}
This study explores the self-efficacies and discretionary behaviours exhibited by managers of small Ghanaian firms with the purpose of understanding how the interplay of these two attributes impacted on employee motivation and performances. The selection of participants was guided by the snowballing technique. Data was collected by distributing self-completion questionnaires entailing managerial self-efficacy and discretionary behavior items to 100 study participants who were managers of small firms in two Ghanaian metropolises. The collected data were analyzed descriptively and inferentially using the statistical package for the Social Sciences software. The results show that the managers had strong senses of affective attachment to their firms due to the use of their self-efficacies to generate dynamic influences on their firms' performances. They also exhibit discretionary behaviours that motivate their employees to work together to achieve organizational goals. The study concludes that the absence of interplay between the managers' self-efficacies and their discretionary behaviours constrains the efficient and effective performances of their firms.
\end{abstract}

Keywords: Small firms, self-efficacy, discretionary behavior, work environment, firm performance

\section{Introduction}

Small firms are known to play important critical roles in the economic and social development of most countries, especially in developing countries south of the Sahara. These firms enhance entrepreneurship development through the creation of jobs with low investment, and also as product suppliers to large companies. Yet, over the years, many small firms in Sub-Saharan African countries could not achieve much, in terms of growth and competitive advantage for them to contribute towards economic and social growth. This was because the managerial behaviours required by managers of these firms to implement and make their business policies functional remained a problematic challenge. This challenge has resulted in the presumption that managers of small firms in most sub-Saharan African countries are not clear about their managerial roles. Many of these managers seemingly have the same jobs roles as their subordinates (Kagire \& Munene, 2007).

In Ghana, the capacities of small firms to translate their business strategies into specific policies have been identified as critical issues that need to be addressed (Sanda, Sackey \& Fältholm, 2011). Though managers of small firms have been found to show a high level of autonomy and influence on the work they managed by using their operant competences most of them were unable to get their competences reflected in the performances and competitiveness of their businesses (Sanda et al., 2011). This inability represented a managerial constraint that could be attributed to the managers' not exhibiting the requisite self-efficacies and discretionary behaviours that could enable the efficient and effective management of their workplaces. A competent manager could be identified as someone who is efficient and effective in using his/her competences to enable positive employee performances and firm productivity. By implication, managers of small firms in Ghana should be able to use their operant competencies to influence the mobilization of their discretionary behaviors in strong positive ways (Simard \& Chênevert, 2010)). The discretionary behaviors of these managers could, therefore, be viewed as important class of behaviors that could be used to understand their managerial performances. This therefore raises the following research question, which this research explored: Do managers of small firms in Ghana possess the relevant self-efficacies and discretion behaviour to motivate employee effective delivery at work?

The purpose this study, therefore, is to answer the question above by understanding how the interplay of managerial self-efficacies and discretionary behaviours that managers of Ghanaian small firms exhibit impact on their employee motivation and firm performances. 


\section{Literature Review}

Self-efficacy is a reliable predictor of both motivation and task performance in organizational settings (Gist, 1987; Wood \& Bandura, 1989), and influences personal goal setting (Wood, Bandura, \& Bailey, 1990). According to Gist (1987), self-efficacy plays a central role in human self-regulation and has strong directive influences on personal goal setting. Bandura (1991) also viewed self-efficacy as a social cognition construct (social learning) which refers to a person's self-beliefs in his or her ability to perform specific tasks. Though self-efficacy has been discussed from the point of view of generative and dynamic influences and its association with performance, Appelbaum and Hare (996) considered the importance of both personal and assigned goals, and their interaction with self-efficacy and performance, as an important theoretical addiction. Thus, reasoning along the line of Appelbaum and Hare (1996), selfefficacy theory can be used at the workplace to understand organizational practices and human resource management issues. Study posited that self-efficacy theory has much to offer with respect to understanding the impact of such change on employees and specific actions to take with respect to training and retraining, communication programs, feedback systems, and goal-setting activities. This is because when self-efficacy beliefs are viewed from Bandura's (1991) description of the human cognitive self-regulation system, they appear as the most central and pervasive influence on the choices that people make. Appelbaum and Hare (1996) exemplified the choices to include the following: (i) goals that people set for themselves, (ii) the amount of effort people expect to apply to a particular task, (iii) the length of time people want to persevere at a task in the face of failure or difficulty, (iv) the amount of stress people want to experience, and (v) the degree to which people want to be susceptible to depression. These five choices reflect self-efficacy as representing a person's evaluation of his/her capabilities against organizational goals, and providing a principal basis for the establishment and re-adjustment of personal goals (Appelbaum \& Hare, 1996).

Based on this, it is argued that managers of small firms could induce higher motivation and organizational performance by strengthening their self-efficacy beliefs through the exhibition of the requisite discretionary behaviours. According to Organ (1988), a discretionary behavior is reflective of the organizational citizenship behavior that is exhibited by an individual in a firm that has the tendency to promote the firm's effective functioning, but which is not recognized directly or explicitly by the firm's formal reward system. Study explained that the display of discretionary behaviours during tasks is not part of individuals' role or job description requirements. Such behaviours cannot be enforced, because they do not constitute clearly specifiable terms of the person's employment contract with the organization. As such, displaying discretionary behavior is a matter of personal choice that links performance and job satisfaction in a meaningful way (Organ, 1988; Moorman, 1991). Simard and Chênevert (2010) viewed the display of discretionary behaviours to be strong when employees have strong levels of affective attachment to the organization. Kagire and Munene (2007) exemplified discretionary behaviours as the showing courtesy and respect to clients, regular attendance and participation in meetings, active promotion of the organization's products and services to people, and following work rules and instructions diligently. Armstrong (2000) noted that the underlying behavior for effective performance by managers can be established by creating their competency profiles. In order to understand what managers do to promote the effective functioning of their organisations, the impacts of their behavior-based competencies (i.e. how they act) and attribute-based competencies (i.e. who they are) must be distinguished. Approaches used include the worker-oriented, the work-oriented and the multi-method oriented (Sandberg, 1994; Veres, Locklear, \& Sims 1990).

In the worker-oriented approaches, the worker is taken as the point of departure, whereas in the workoriented approaches, the work is taken as the point of departure (Fine, 1988; Flanagan, 1954). In the work-oriented approach, activities that are central to accomplishing specific work are identified and transformed into personal attributes. Raven (1984) criticized the work-oriented approaches as listing of work activities does not sufficiently indicate the attributes required to accomplish the activities efficiently. In the worker-oriented approach, competency is viewed as a measure of person's individual attributes that is required for effective work performance (Veres et al., 1990). Such individual attributes include the person's knowledge, skills, abilities and personal traits. In this study, the managers' discretionary behaviours informed by their personal traits attributes are tested as competency measure for effective work performance.

\section{Methodology}

The target population of this study was managers of small firms in two Ghanaian metropolises. A selfcompletion questionnaire entailing self-efficacy items (see table 1 below) and managerial behavior items 
(see table 2 below) was used as the data collection tool. For instance, "find new ways of doing things, and being practical"; Cronbach's alpha was 0.85 . The response ratings followed the four-point Likert scale from rarely (1) to very often (4). In the data collection approach, the snowballing technique (Patton, 1990) was used to identify suitable study participants. By this technique, respondents who agreed to participate in the study were used as platform to identify other willing participants. One hundred (100) participants were identified as data sources. The questionnaires were handed over to each respondent by the researcher. The researcher explained the purpose of the study to the respondents and guaranteed their anonymity and confidentiality of the information provided. All the 100 questionnaires administered were returned with all sections fully scored. Data was analyzed using the statistical package for social sciences (SPSS) software. The scale scores were computed by averaging across responses to the items in each scale. Pearson correlation coefficients were computed and used to determine the degree of association between the managerial behavior attributes and the creation of work environment for high performance. This facilitated the establishment of the findings, interpretations and conclusions, as it is highlighted in the subsequent sections.

\section{Table 1: Managerial Self-efficacy Items in the Questionnaire}

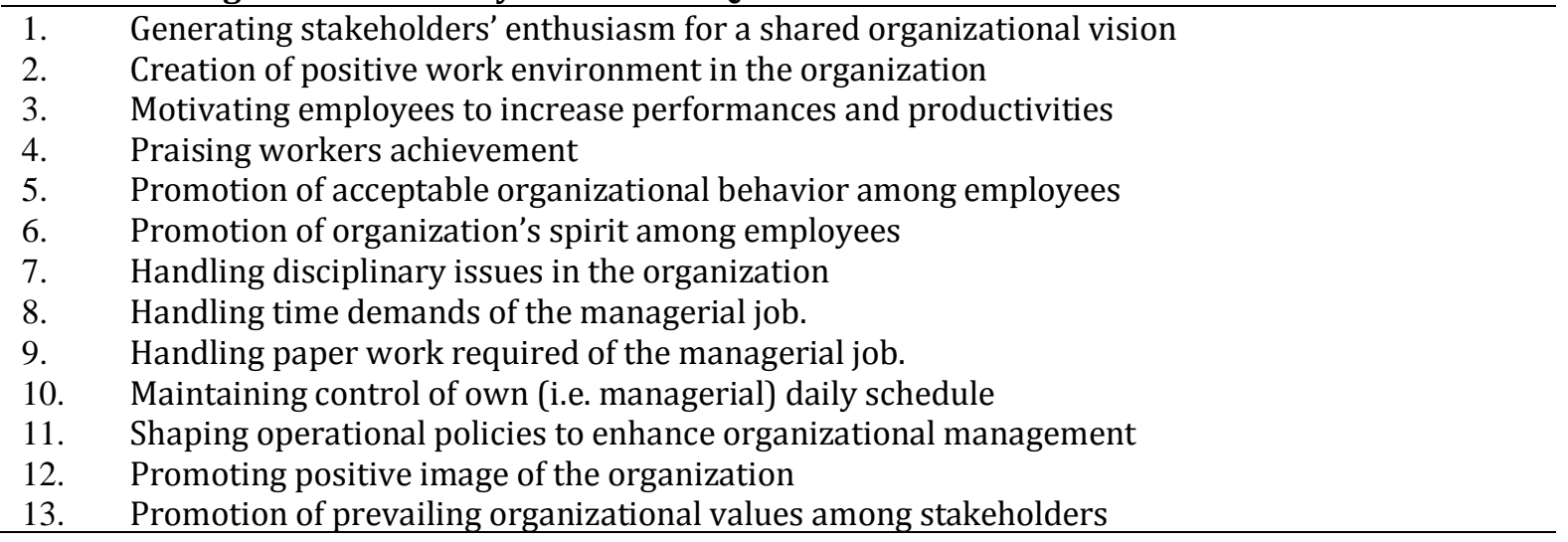

Table 2: Managerial Behaviour Items in the Questionnaire

Managerial Behavior Attributes
Working to achieve results and improve
individual and organizational contribut
Ensuring smooth set up of operational
systems.

systems.

Ensuring that employees are motivated to work together to achieve organizational goals

Ensuring that activities are planned to create a desired work environment

Making an effort to communicate clearly with every staff

Trying to find and create valuable, useful new products, services, ideas, procedures or processes

Ensuring that emotions and behaviors of oneself and others are managed in a social interactive context

\section{Determining Factors}

Meet deadlines.

Praise good performance.

Encourage excellence among the team.

Take risks in the interest of the organization.

Determining the kind of tools and equipment needed to do a job.

Determining causes of operational errors and deciding what to do.

Conducting tests and inspections of products and

Delegate and empower staff.

Make quick decisions.

Work hard and set pace for the team.

Motivate employees

Involve staff in decision making

Put resources to their efficient and effective use.

Listen to the ideas of others

Give feedback

Find new ways of doing things.

Be practical

Understand workers issues not related to work but with impact on work performance.

No personal offence taken when criticized.

Value and work with subordinates 


\section{Results and Discussion}

The results obtained are analyzed and discussed from the perspectives of the following two themes: (i) Descriptive analysis of the managers' self-efficacy, and (ii) Descriptive and correlation analyses of the managers' managerial behaviours.

Descriptive Analysis of the Managers' Self-Efficacies: The descriptive assessment of the combination of the managers' ability, resources and opportunity shows that $65(90.3 \%)$ of them handle the time demands of their job and are able to maintain control of their own daily schedule. Sixty-one (84.7\%) of them handle the paper work that is required of the job. Additionally, by shaping the operational policies and procedures that are necessary to manage their organization, as well as prioritizing among the competing demands of their jobs, these managers are able to cope with the stresses of their jobs. Sixtytwo (86.1\%) managers create positive working environments in their organizations by promoting acceptable behavior among their workers. They motivate their workers to put in more effort at their job by facilitating them on their jobs, as well as appraising their achievements on standardized tests. Sixty $(83.3 \%)$ of them also indicate that they generate enthusiasm for a shared vision by promoting organization spirit among a large majority of their workers, which event make it possible for them to inculcate discipline among their workers, and thus manage change in their organizations. It also emerges that $63(87.5 \%)$ of the managers use the combination of their current ability, resources and opportunity to promote positive images of their organizations by promoting the prevailing values of their organizations' communities, as well as the ethical behavior among fellow managers.

The analysis above shows that the managers' have a strong sense of affective attachment to the organization (Simard \& Chênevert, 2010) which characteristics signify superior performance. Such strong of affective attachment to the organization can be attributed to the interaction between the managers' self-efficacy and their abilities to generate dynamic influences on their firms' performances. This signifies the importance of self-efficacy as a reliable predictor of both motivation and task performance in organizational settings (Gist, 1987; Wood \& Bandura, 1989). The managers' attitude of praising good performance, encouraging excellence among employees, and taking risks in the interest of their firms enhance their capacities of working to achieve results. The managers identifying the causes of operational errors, and deciding what to do, is expressive of their managerial behaviours towards the smooth set up of their firms' operational systems. The involvement of staff in decision-making portrays the managerial behavior of creating a desired work environment. Also, the managers' delegation of tasks and power is indicative of managerial behavior towards raising employee motivation in working to achieve organizational goals. By delegating, it is imperative that the managers allow for the existence of freed om in work activities which motivate employees to work towards the realization of their firms' goals. This, according to Kim (2004), is because, once freedom, support from management, and directions are present, workers are truly empowered to give their very best to the organization. In this respect therefore, most managers of small firms in Ghana exhibit the requisite organizational citizenship behavior attributes that enable them to plan activities in their firms effectively. This behaviour also enables the managers to create conducive work environments for their employees, and also to motivate them (i.e. employees) to work towards achieving organizational goals. By this behavior, the managers are able to show the self-efficacies of evaluating their capabilities against organizational goals (Appelbaum \& Hare, 1996).

Descriptive and Correlation Analysis of the Managers' Managerial Behaviors: The study seeks to find out whether there is an influential relationship between the managers' behavior attributes and their competence in creating a work environment for high performance. The managerial behaviours exhibits by the managers are analyzed. The influence of the managerial behaviours in creating work environments for high performance (CWEHP) is also analyzed using the Pearson correlation coefficients shown in table 3 below.

Manager's Behavior in Working for Results: Descriptive assessment of how the managers behave when working towards achieving results and improving individual and organizational contribution shows that $61(85.9 \%)$ of them most often meet deadlines set for organizational activities. Fifty-nine (81.4\%) of the managers most often praise their staff whenever they exhibit good performances, with only 4 (5.6\%) of them indicating that they do not praise performance. Sixty-seven $(88.8 \%)$ managers note that they encourage excellence among the work teams in their firms, with only $53(73.6 \%)$ of them indicating that they take risks in the interest of the organization. The implication here is that the managers' have the 
attitude of praising good performances, encouraging excellence among employees, and taking risks in the interest of their firms in order to enhance their capacities of working to achieve results. Therefore, the managers exhibit the requisite managerial behavior attributes that allow for the improvement of individual and organizational contribution towards the achievement of results. Pearson correlation analysis (see table 3) shows that the above managerial behaviours which the managers exhibit towards achieving results and improving individual and organizational contribution significantly enhanced their capacities in creating work environments for high performance $\left(\alpha=.540^{* *}\right)$. The finding in this analysis show that the managers' use of their managerial behaviors to motivate and increase employees' behavior and in-role performances is important to the well-being of the firm. Arguing along the lines of Organ (1988), possession of such performance enhancing indices is important for business managers. This is because such indices differentiate the managers from their subordinates (Organ, 1988; Du Gay, Salaman \& Rees, 1996).

Manager's Behavior in Setting up Firm's Operational System: With regard to the managers' actions in ensuring the smooth set up of their firms' operational systems, the descriptive analysis shows that 58 $(80.5 \%)$ of them most often determine the kind of tools and equipment that workers need for their jobs beforehand. Fifty-four (81.9\%) managers most often engage themselves in determining causes of operational errors when they (i.e. errors) occur, and proceeding on to decide on what to do in order to address such errors. Fifty-nine (82\%) of the managers indicate that they conduct tests, and as carry out inspections of their firms' products and services. The implication here is that the managers' attitude of identifying the causes of operational errors and deciding on what to do project them as persons whose managerial behaviours allow for the smooth set up of their firms' operational systems., as well as the testing and inspections of their products and services. Pearson correlation analysis (see table 3 ) shows that the above managerial behaviours which the managers exhibit towards the smooth set up of their firms' operational systems, significantly enhance their capacities in creating work environments for high performance $\left(\alpha=.502^{* *}\right)$. The manager's creation of functional systems and good working environments show that they possess behaviors that enhance their competencies towards firm performance for sustained competitive advantage (Barney, 1991).

Table 3: Pearson Correlation between Managers' Managerial Behavior Attributes and CWEHP

\begin{tabular}{lc}
\hline \multicolumn{1}{c}{ Managers' behavior attributes } & CWEH ( $\boldsymbol{\alpha})$ \\
\hline $\begin{array}{l}\text { Working to achieve results, and improving individual and organizational } \\
\text { contribution }\end{array}$ & $.540^{* *}$ \\
$\begin{array}{l}\text { Ensuring the smooth set up of operational systems } \\
\text { Ensuring that employees are motivated to work together to achieve }\end{array}$ & $.502^{* *}$ \\
$\begin{array}{l}\text { organizational goals } \\
\text { Ensuring that activities are planned to create a desired work environment. }\end{array}$ & $.519^{* *}$ \\
$\begin{array}{l}\text { Making efforts to communicate clearly with every staff } \\
\text { Trying to find and create valuable, useful new products, services, ideas, }\end{array}$ & $.558^{* *}$ \\
$\begin{array}{l}\text { procedures or processes. } \\
\text { Ensuring that emotions and behaviors of oneself and that of employees are } \\
\text { managed in a social interactive context }\end{array}$ & $.486^{* *}$ \\
\hline
\end{tabular}

Manager's Behavior in Creating Useful Procedures: The descriptive analysis show that, in trying to find and create valuable, useful new products, services, ideas, procedures or processes, $59(82 \%)$ of the managers engage themselves in finding new ways of doing things well. Fifty-seven (79.2\%) managers also indicate that they always tend to be practical in their approaches. As such, the managers' ability of finding new ways of doing things, and being practical show them as possessing the managerial behavior attribute for finding and creating valuable, useful new products, services, ideas, procedures and/or processes. Pearson correlation analysis (see table 3) shows that the managers' managerial behavior significantly influences their work towards finding and creating valuable, useful new products, services, ideas, procedures or processes and the creation of work environments for high performance $\left(\alpha=.496^{* *}\right)$. This findings indicates that the managers' by virtue of their managerial behaviours follow work rules and instructions diligently, behave courteously and respectfully to their firms' stakeholders, and actively promote their organizations' products and services to client (Kagire \& Munene, 2007)

Manager's Behavior in Motivating Organizational Goal Attainment: The descriptive analysis shows that $57(79.2 \%)$ managers mostly use the medium of delegation and staff empowerment to motivate their 
employees to work together to achieve organizational goals. Fifty (69.5\%) managers note that they use the medium of quick decision-making as a tool for employee motivation. In the same vein, $60(83.4 \%)$ of the managers are able to motivate their employees to work together to achieve organizational goal by they (i.e. managers) setting the pace for hard work. Pearson correlation analysis (see table 3 ) shows that the mangers' managerial behavior significantly influences their work towards ensuring that employees are motivated to work together to achieve organizational goals and the creation of work environments for high performance $\left(\alpha=.519^{* *}\right)$. The finding in this analysis corroborates the view that once employees perceive the behaviours of their managers as a source of empowerment, they (i.e. employees) will psychologically pursue organizational goals with meaningfulness, competence, and self-determination (Dennison, 1984), which will lead to organizational effectiveness (Lee \& Koh, 2001). Empowerment within an organization, therefore, gives rise to the intensity of effort (Kim, 2004). The results from the analysis also shows that empowerment gives freedom for workers to seize the initiative, take risks, volunteer ideas, solve problems on their own, and free to speak their minds (Birren, 1996). The consequence of the managers' behaviours in motivating the employees reflects the argument by Organ (1988) that it is very important to motivate employees, not only to increase their in-role performances, but also to engage the employees in citizenship behaviours that are important to the well-being of the organization.

Manager's Behavior towards Planning: The descriptive analysis shows that 50 (69.4\%) managers mostly involve their staff in decision-making in order to ensure that they plan their firms' activities to create a desirable work environment. Fifty-eight (80.6\%) managers create desirable work environments by putting organizational resources to their efficient and effective use. In this respect therefore, most managers of small firms in Ghana posses the requisite organizational citizenship behavior attributes that enable them to plan activities in their firms in order to create desirable work environments, and also to motivate their employees to work together to achieve organizational goals. Pearson correlation analysis (see table 3) shows that the managers' managerial behavior in planning firm activities significantly influences their ability to create work environments for high performance $\left(\alpha=.558^{* *}\right)$. This finding indicates that the managers are able to mobilize their behaviours strongly and positively by ensuring that their employees have a strong level of affective attachment to the organization (Simard \& Chênevert (2010).

Manager's Behavior towards Employee Emotion and Behavior: The descriptive analysis shows that $56(77.8 \%)$ managers try to understand very well workers issues that do not relate directly to the jobs in the firm. These are issues that can impact on employee work performances. By understanding such issues, these managers are able to manage their personal emotions and behaviours as managers, and also that of their employees and others associated with their firms in a social interactive context. Fifty-one $(70.8 \%)$ managers note that they do not take offence when their employees criticize them (i.e. managers). Sixty-two (86.1\%) managers also indicate that they are able to manage their self-emotions as well as that of others by working with and valuing their subordinates. These results imply that most managers of small firms in Ghana possess the requisite behaviours that enable them to communicate clearly with employees. The descriptive analysis shows that 61 (84.8\%) managers listen to the ideas of their employees. Fifty-nine 59 (81.9\%) managers indicate that they give feedback. Pearson correlation analysis (see table 3) shows that the mangers' managerial behavior significantly influences their work towards making efforts to communicate clearly with every staff and the creation of work environments for high performance $\left(\alpha=.486^{* *}\right)$. The managers' behaviours also enable them to manage their self-emotions and self-behaviours, as well as those of their employees in a social interactive manner. Pearson correlation analysis shows that the managerial behavior that the managers use to manage their personal emotions, and also that of others in a social interactive context contributes significantly to their abilities to create work environments for high performance $\left(\alpha=.442^{* *}\right)$. The managers' ability to motivate their employees towards high organizational performances is a result of using their self-efficacy beliefs to strengthen their managerial behaviours when setting organizational goals (Appelbaum and Hare, 1996). Arguing from the viewpoint of Boyatzis (1982), the managers' managerial behaviours are reflective of their underlying characteristics that relate causally to efficient and effective performance. Efficient performance in this regard is the use of requisite managerial behavior to generate optimal performance (i.e. without wastage) in order to achieve organizational goals. Effective performance is the use of requisite managerial behavior to attain the organization's set goals. The managers' acceptance of criticism from their employees and the understanding they show on employee-issues is a portrayal of managerial behaviour that allows them to function effectively. The managers therefore possess specific behaviours that encourage effective or superior performance (Mansfield, 1999). 


\section{Conclusion and Recommendation}

Based on the results and discussion, the managers of small firms in Ghana could be perceived as having shown a high level of autonomy and influence on the work they manage by appreciably combining their operant competences and their organizational citizenship behaviours. As such, it can be argued that the managers' use of their operant competencies has had a strong independent positive influence on the mobilization of their discretionary behaviours (Simard \& Chênevert, 2010)). By implication, and in consonance with the suggestions of MacKenzie et al. (1991), organizational citizenship behavior (Organ, 1988) is apparently an important class of behaviours that reflects on the overall managerial performance of SME managers in Ghana. Yet still, it is an issue of phenomenal interest for this study that despite the managers exhibiting competence and organizational behavior attributes, as discussed above, these characteristics appeared not to have affected positively on their performances towards making their organizations competitive. In this regard, it is concluded that; since managers of small firms in Ghana possessed the requisite self-efficacy and discretionary behaviours to enhance the performances of their firms, their inability to make such competences reflect in the performances of their businesses might be due to their inabilities to simultaneously attain efficiency and effectiveness in the management of their workplaces. It is also concluded that; for the managerial behavior attributes of the manager to become visible and positively influencing the small firm, the manager must be seen to be efficient and effective. For the manager to be efficient, he/she should have the capability to use his/her requisite managerial behavior optimally (i.e. without wastage) to achieve organizational goals. For the manager to be effective, he/she should have the capability to use his/her managerial behavior toward attaining the firm's goals.

\section{Recommendations}

This research is relevant for the reason that it has provided both practical and theoretical insights into aspects of the challenges relative to the management of small firms in Ghana. The findings made on the competences and organizational citizenship behavior among the managers could help sustain and support the achievement of the intended organizational and individual outcomes required of Ghanaian small firms within a competitive world of work. The outcome of this research contributes to the sum total of knowledge in the study and practice of organizational citizenship behavior and operant competences in the field of human resource management. Specifically, for Ghana, this research provides a platform for the development of a database that will help inform policy-makers on the requisite competences and organizational citizenship behavior to be required of managers of small firms in managing businesses. Focusing the study on managers of small firms in Ghana alone is a limitation, since a study of other countries could also have provided data with a broader perspective, and which could have had an impact on the results obtained.

\section{Reference}

Armstrong, M. (2000). Performance Management: Key Strategies and Practical Guidelines. London: Kogan Page.

Appelbaum, S. H. \& Hare, A. (1996). Self-Efficacy as a Mediator of Goal Setting and Performance: Some Human Resource Applications. Journal of Managerial Psychology, 11(3), 33-47.

Bandura, A. (1991). Social Cognitive Theory of Self-Regulation. Organizational Behavior and Human Decision Processes, 50(2), 248-287.

Barney. J. B. (1991). Firm Resources and Sustained Competitive Advantage, Journal of Management, 17(1), 99-120.

Birren, J. E. (1996). Encyclopedia of Gerontology: Age, Aging, and the Aged. San Diego, CA: Academic Press. Boyatzis, R. E. (1982). The Competent Manager: A Model for Effective Performance. New York: Wiley.

Dennison, D. (1984). Bringing Corporate Culture to the Bottom Line. Organizational Dynamics, 13(20), 422.

Du Gay, P. Salaman, G. Rees, B. (1996). The Conduct of Management and the Management of Conduct: Contemporary Managerial Discourse and the Constitution of the 'Competent' Manager. Journal of Management Studies, 33(3), 263-282.

Fine, S. A. (1988). Functional Job Analysis. In Gael, S. (Ed.). The Job Analysis Handbook for Business, Industry and Government (79-103). New York: Wiley.

Flanagan, C. J. (1954). The Critical Incident Technique. Psychological Bulletin, 51(4), 327-358. 
Gist, M. E. (1987). Self-Efficacy: Implications for Organizational Behavior and Human Resource Management. Academy of Management Review, 12(3), 472-485.

Kagire, J. R. K. Munene, J. C. (2007). Engineering Lecturers' Competencies and Organizational Citizenship Behavior (OCB) at Kyambogo University. Journal of European Industrial Training, 31(9), 706-726.

Kim, A. (2004). Parent-School Partnership Formation through the School Council in Korea. Educational Research for Policy and Practice, 3(2), 127-139.

Lee, M. \& Koh, J. (2001). Is Empowering Really a New Concept? Journal of Human Resource Management, $12(4), 684-695$.

Mackenzie, S. B. Podsakoff, P. M. \& Fetter, R. (1991). Organizational Citizenship Behavior and Objective Productivity as Determinants of Managerial Evaluations of Salespersons' Performance. Organizational Behavior and Human Decision Processes, 50(1), 123-150.

Mansfield, B. (1999). What is Competence All About? Competency and Emotional Intelligence, 6(3), 24-28.

Moorman, R. H. (1991). Relationship Between Organizational Justice And Organizational Citizenship Behaviours: Do Fairness Perceptions Influence Employee Citizenship? Journal of Applied Psychology, 76(6), 845-55.

Organ, D. W. (1988). OCB: The Good Soldier Syndrome. Lexington, MA: Lexington Books.

Patton, M. Q. (1990), Qualitative Evaluation and Research Methods. Newbury Park, CA: Sage.

Raven, J. (1984). Competence in Modern Society: Its Identification, Development and Release. Oxford, England: Oxford Psychologists Press.

Sanda, M. A. Sackey, J. \& Fältholm, Y. (2011). Managerial Competence and Non-Performance of Small Firms in a Developing Economy. International Journal of Contemporary Business Studies. 2(3), 624.

Sandberg, J. (1995). Are Phenomenographic Results Reliable? Journal of Nordic Educational Research, 15(3), 156-164.

Simard, G. \& Chênevert, D. (2010). Organizational and Individual Determinants of Atypical Employment: The Case of Multiple Jobholding and Self-Employment in Canada. Canadian Journal of Career Development, 9(1), 25-33.

Veres, J. G. Locklear, T. S. \& Sims, R. R. (1990). Job Analysis in Practice: A Brief Review of the Role of Job Analysis in Human Resources Management. In: Ferris, G. R. Rowland, K. M. Buckley, R. M. (Eds.). Human Resource Management Perspectives and Issues (pp. 79-103). Boston, MA: Allyn and Bacon.

Wood, R. \& Bandura, A. (1989). Social Cognitive Theory of Organizational Management. Academy of Management Review, 14(3), 361-84.

Wood, R. Bandura, A. \& Bailey, T. (1990). Mechanisms Governing Organizational Performance in Complex Decision-Making Environments. Organizational Behavior and Human Decision Processes, 46(2), 181-201. 